\title{
Transformation of indigenous peoples' Ecological conciousness
}

\author{
Oksana Shostak ${ }^{1, *}$, Liubov Drotianko ${ }^{1}$, and Vira Bazova ${ }^{1}$ \\ ${ }^{1}$ National Aviation University, 1 Liubomyra Huzara ave, Kyiv, Ukraine
}

\begin{abstract}
The world of Indigenous ecological reality has a spatial and temporal structure. The need for a favorable natural environment, sufficient natural resources' quantity and quality, as well as environmental security has been permanently present in autochtonous existence. Researchers of North American and Siberian indigenous peoples' ecological identity agree that of the two criteria, spatial structure plays more important role than temporal. The indigenous peoples' spatial identity is linked to their deep conviction that everything in the world "stops" periodically, so if you pray in the right locality, where higher powers are most likely to stop at that very moment, prayer would be heard. Thus the feeling of attachment to ethnic homeland is crucial in the process of creating an ethnic niche. Most of the Indigenous people believe that their nations were created at the territory they live now, so this locus is the center of the universe for them. The past and the future are understood by the natives at the level of physical perceptible sound, visual, tactile and sensory sensations, thus the concept of the sacred landscape is formed, and each nation has its own notion of it. Indigenous writers sometimes shift temporal-spatial layers, superimposing chronotopic planes, suspending astronomical time, thus destroying the boundaries of the real world and at the same time creating fascinating spaces that are an important part of the indigenous spatial identity. Thus, spatiality functions in fictional texts as a stylistic device designed to express the opposition of different worlds.
\end{abstract}

\section{Introduction}

Ecologic and ethnic problems are one of the most painful issues of the modern world, this phenomenon has become a reaction to the spiritual culture unification in the context of globalization. That is why the last quarter of the twentieth century and especially the beginning of the XXI century is marked by the problem of differences actualization, and not only ecological, but also cultural, gender and racial. Therefore, the present time is marked by a wave of ecological revivals, which are perhaps the most decisive for the mankind development in the XXI-st century. There is an interest in finding one's own roots chased by a deep influence of folklore on the professional culture representatives. Stephen Hansaker emphasizes that portraying oneself as a nationalist is not a matter of appropriating preconceived political attitudes, but rather opposing previous ecological identity models in order to create new, unrestricted or more comfortable models of nationalism [1].

*Corresponding author: oshostak@ukr.net 
The world of everyday reality has a spatial and temporal structure [2], as Lev Gumilev complements this opinion with the thesis that "the interaction of mankind with nature is constant, but this process varies greatly in space and time" [3]. Researchers of North American and Siberian indigenous peoples' national identity agree that of the two criteria, spatial structure plays more important role than temporal. Thus Vine Deloria Jr. proposes the term "bioregional worldview" [4] to describe the American Indians and the Indigenous peoples' of Siberia worldview. This term is based on the belonging to a specific space, land and its landscape. Nowadays, any person, whether he knows it or not, is the bearer of many human history's epochs. The most different layers are whimsically combined in human: Asia and Europe, East and West, Christianity and Paganism, regional and federal, province and capital, folk and classical, Antiquity, the Middle Ages, modern times technocracy and patriarchy .A sense of unity with a particular territory is an important theme in the literary tradition of the American and Canadian Indians and Indigenous peoples of Siberia : The Way to the Rainy Mountain by N. Scott Momaday, Pushing the Bear by Diane Glance, I Listen to the Earth, Khanty, or the Star of the Morning Dawn by Eremej Ajpin, Song of the Nivkhs by Vladimir Sangi.

\section{Materials and method}

Methodological approach, which will consider the peculiarities of the perception of temporal and spatial identity of indigenous peoples in the context of cultural and literary transformations, that takes place in the context of globalization since the late XX-th century. An important role belongs to the method of cultural and semantic analysis, which would explore changes in the national temporal and spatial identity linguistic and literary content of the different cultures of Siberia and North America representatives.

The subject specificity of the research determines the methodological basis, which is grounded upon the spatial identity of the Siberian and North American literary works. The methodological basis of the study were the works of Aleksandr Vashchenko, Lev Gumilev, Louise Owens, N.Scott Momadey, Susan Scarberry-Garcia, Paula Gunn Allen, Vasil Balushok, Oksana Shostak.

\section{Results}

The indigenous peoples' ecological identity is linked to their deep conviction that everything in the world "stops" periodically, so if you pray in the right locality, where higher powers are most likely to stop at that very moment, prayer would be heard. These spots were marked by special stone constructions, which represented various animals or "sacred circles". The sacred circle was placed at the highest point of the landscape, from which one could see the land of a particular tribe. The spokes of the wheel pointed to the sacred objects. Generation after generation studied their land with the help of these circles. These objects were not just signposts, but also calendars. In their silent and timeless space, the sacred circles unite people with the supreme forces, the earth and the endless line of generations of ancestors [5]. The past and the future are understood at the level of physically perceptible sound, visual, tactile and sensory sensations, thus to form the concept of a sacred landscape each nation has its own representatives incomprehensible for other indigenous nations.

The ecological identity is based upon the fact that space itself is impossible to imagine without those who occupy a certain room in it, a person has a constant connection to the birthplace where he comes from, as well as with the site of his location at the moment. Martin Heidegger wrote that the human existence is defined by the attendance in the world,and 
not simply bodily presence. Thus, from the very beginning, indigenous people's identification took place within a certain situation, due to the person's birth locality in a certain environment, as well as his belonging to a particular linguistic and cultural tradition. This is a dialectic between internal self-identification and external social origin [6]. Louis Owens said that people of all tribes have always had strong ties to the land where sacred ancestral bones were buried, these places were associated with sacred traditions that explained to people who they really are, what are their origins and how they should live in the world around them. Almost all tribes had so-called migration histories, which told where they came from before finding their own home. The very fact that the displaced nations of the southeast were able to conquer Indian territory after all the horrors of displacement proves the ability of Native Americans to move preserving the culture and traditions of the nation [7].

A. Josephie notes that in pre-Columbian times continents' population was small, certain groups of people interacted, united, and divided into new communities, pushing each other into less accessible or disadvantaged areas. Ten thousand years ago, these groups shared the territory of North America and Siberia with mammoths, mastodons, huge bison and bears, giant sloths, small prehistoric horses and other animals of the ice age. At the end of this period, the giant glaciers retreated and the earth took on a new shape. The tundra and evergreen forests on the south edge of the glaciers moved north, and the area where the glaciers were located was occupied by vast grass prairies, hardwood forests, deserts, and mountain plateaus. Two thousand years later, all mastodons, giant sloths, ponies, saber-toothed tigers and many other animals of the ice age became extinct. In many parts of the continent, people have studied smaller animals that survived with them, changing their hunting methods, the size of their spears, along with deer, antelopes and other small animals, while relying on fish and shellfish and collected nuts, berries, herbs, seeds and wild vegetables and fruits. Over time, different groups of people began to identify themselves with specific land areas, associating them with the places of origin of their ancestors or places created for them by the Creator or other supernatural beings. Century after century, they strengthened spiritual ties with a particular territory, learning to understand and care for its resources, and in return receiving everything necessary from it [5]. As the population grew and the ancient Indians adapted to the diverse natural environment, cultural and physical differences began to emerge. Those who lived on the ocean coast created a sea-oriented culture, their economy depended on fishing and collecting mollusks and shells. In the eastern forests and in California, foresters learned to use fire to clear the ground for new seedlings, which in turn increased the population of deer and other animals. In the Canadian North, hunters learned to ski in search of caribbean deer and use animal mannequins to lure timid animals into hunting grounds.

Edible crops such as sunflower and corn were cultivated in the eastern forests. In every part of the continents, indigenous peoples built relationships with their land, harmonizing their needs with what nature could give them, and spiritual life with the spirits of the universe around them.

Joshua Miner is convinced that even the practice of mapping indigenous peoples is based on the cultural tradition of each people. "Indigenous mapmaking practices are rooted in unique cultural traditions. Native maps operate not just as tools of physical orientation, as their Eurowestern counterparts do, but also more deeply as storied pictures. They provide direction because they depict social and spiritual relationships between people, other species, and their environments through time and space. Indigenous cartographic conventions, as they manifest through story traditions, shape responses to all aspects of Native life. Yet, since they sit at a more intimate node between culture and environment, they are especially significant during forced migration, which seeks to sever such relationships. In these cases, story and geography reveal a new interdependence: Native story traditions function as 
mapmaking practices at heart, as they serve the manifold role of cultural sustainment during emigration, establishing a link to former homelands, and emplacement in a new environment." [8].

European land ownership in the XVI-XVII centuries meant independence and financial stability. The land is exactly what called the densely populated countries of inhabitants of Europe to Siberia, the newly discovered continents of America, and it is the affiliation to this land that made its indigenous people "indigenous." However, the very concept of "land ownership" was alien to them, they did not detach themselves from it, they considered themselves part of it. This fact can still be well observed in the worldview models of Indians of different tribes. K. Lincoln wrote that "the tribe feels one with the earth" [9].

L. Gumilev notes that, despite the development of technical progress, the basis for supporting human life is nature. People are the "final link in the biocenosis of the region where they live", they are elements of structural and systemic integrity, it also includes domestic animals and cultivated plants, landscapes (both man-made and primitive), the richness of the subsoil, and one or another combination of languages and elements of material and spiritual culture. This dynamic system can be called an ethnocenosis. $<\ldots>$ Each process of ethnogenesis leaves deep traces on the body of the earth's surface, thanks to which it is possible to establish the general characteristics of the development of ethnic history" [3].

Vasyl Balushok proposes the concept of ethnic niche, due to which the essence of the ethnic subconscious is formed. In the process of adapting to natural and social conditions, in the time flow it becomes more dominant in the community and the corresponding cultural realities, so mental traits appear, which are then realized, as a result the ethnic selfconsciousness emerges. "Under the ethnogenetic niche is proposed to understand the local region of the terrestrial ecumenism, which stands out among other similar regions for its natural-geographical and related socio-cultural characteristics, and which, being united by a single network of communications (among them the main role play information), is a certain integrity. Ethnogenetic niche, influencing the population located on its territory, is the cause of the formation of the ethnos" [10]. This thesis of the researcher continues the opinion of L. Gumilev, who is convinced that "in different geographical regions and in different epochs people and natural complexes (landscapes and geobiocenoses) interact differently. There is a constant correlation between the laws of nature and the social form of motion of matter" [3].

Andrew MacDonald argues that "the key concept of the Indian way of life is the constant unity of time and space." The researcher is convinced that this unity should be understood in terms of Einstein's theory, the postulates of which have long been known to Native Americans and are the basis of their cosmology [11]. A person in the native cosmogony never "choses" sacred spaces on his/her own, instead sacred places were opened to human by hierophany, so the loss of these places as a result of any event was considered a catastrophe.

The feeling of attachment to ethnic homeland is crucial in the process of creating an ethnic niche. A clear example of this is the fate of Native American tribes which were forcibly evicted from their homelands after the United States government passed a law in 1830 to relocate all Indigenous people east of the Mississippi River (thus creating the socalled Native American territory). The deportation was brutal, with the involvement of military force, as a result of which a wave of local wars swept the country with the Native population. During military operations, the Indian resistance was broken. But even after the total bloodshed, the eastern part of the country could not be completely liberated from its indigenous population. Many members of the Confederacy of the six Iroquois nations, continued to inhabit New York State, the Seminoles remained in Florida, the Chocto in Alabama, the Cherokees in the Southern Appalachians. As for Algonquins, who had the misfortune to be the first to encounter hordes of white settlers, most of them had to hide for 
a long time in uninhabitable mountainous and swampy areas, but they did not leave their homeland. Paula Gunn Allen notes that virgin nature exists in the blood of every Indian, and it will remain there as long as the grass grows, the wind blows and the rivers flow, as long as there is at least one Indian woman left in this world [12]. Gumilev emphasizes that "ethnic groups is a phenomenon that stands on the border of the biosphere and sociosphere, so they have a very specific purpose in the structure of the Earth's biosphere" [3].

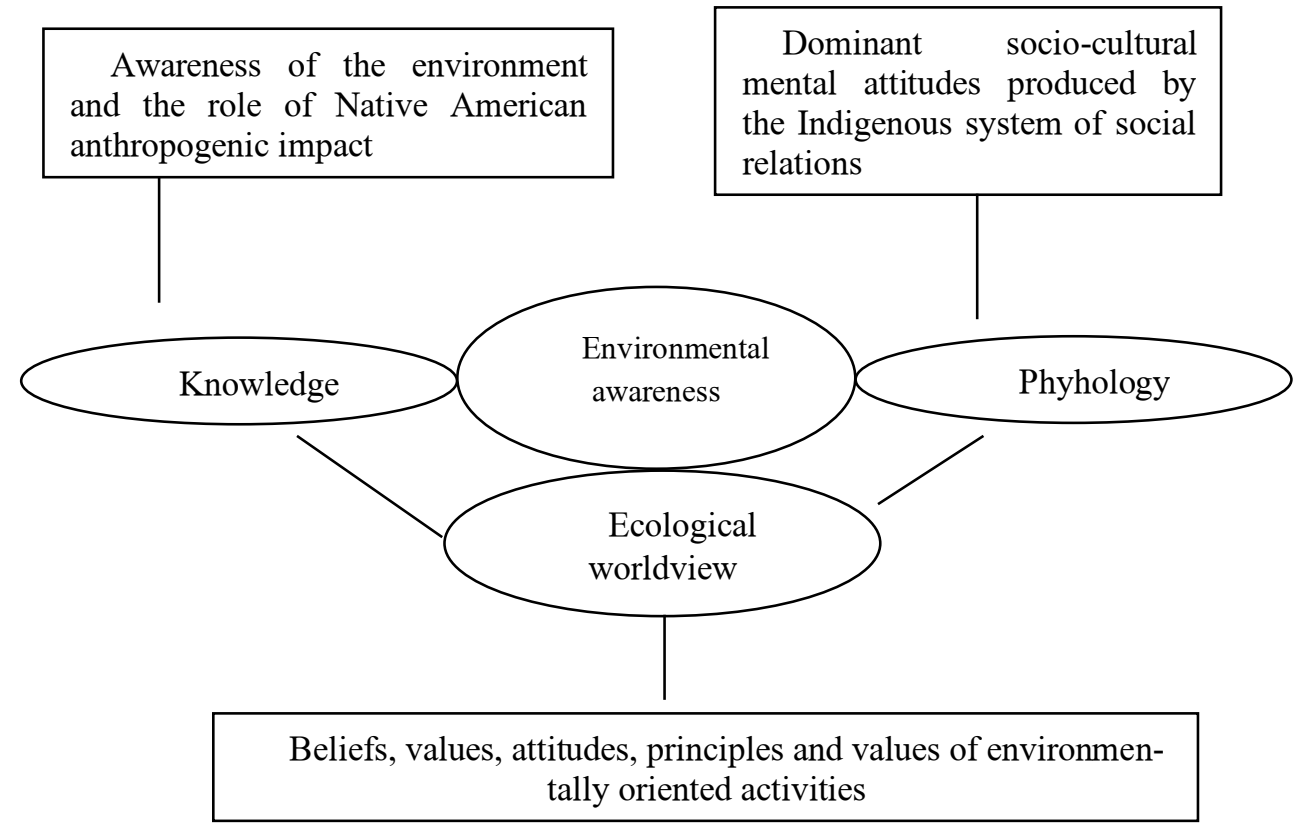

Fig. 1. The main components that influence the transformation of Indigenous environmental consciousness.

The phenomenon of native land is becoming almost the main factor in the indigenous ethnic groups formation. "Ethnic fluidity is a kind of remnant of the proto-ethnic state of human communities, characteristic of early hunter-gatherers, who struggles with the transition to sustainable settlement, concentration of population in certain local areas and the emergence of political structures in the final primitive stage" [10]. Such fluidity is radically different from the "ethnicity of settled peoples, firmly attached to their own ethnic territories, manifested in the continuous process of reorganization, transition of individual groups, whole clans and ethnic units from one ethnic group to another, merging small communities into larger and smaller [10].

Usually, the boundaries of identity rarely coincide with the borders of nation-states. Therefore, any human identity, whether personal, cultural or national, is, first of all, a spatial identity, because it is determined not by the borders of the state, but by its life situation, where markers of this identity are formed. Indigenous identity researcher of North America J. Tripathy argues that despite the fact that there is no standardized indigenous North American (due to the highly developed "internal heterogeneity"), the indigenous people of the continent have a collective sense of foundations rooted in their lands and the way of life of the tribes, they represent the most primordial and unchanging perception of life among all the ethnic groups of North America [13].

Gerald Vizenor and Jill Doerfle (Ojibwa) wrote that the depletion of indigenous lands and the capitalization of natural resources, such as minerals, water, and forests, were a corporate strategy, not a sporadic expression of the Yomen's will. The nature of birds and 
animals was an elusive component on which the totemic ideas of the natives were based, all of which was trampled for profit and democratic commerce. Despite all the irony of such "democracy", ambiguity and betrayal, communication with the land and totemic associations that now emerge as cultural sovereignty, in the transmission of spiritual values to future generations, in memories of the continent's former freedom are now an important part of indigenous literary tradition [14]. Diana Glancy in Pushing the Bear attempts to convey the complexity and importance of sacred geography to displaced Cherokees, and Leslie Marmon Silko in Ceremony analyzes the spatial identity of the Pueblo Laguna in the context of uranium contamination of their original lands [15].

The national identity of the United States people is characterized by the rupture of ties, which, in turn, produces individualism, "which serves as the cementing principle of America from the first steps of its settlers to the present" [16]. Individualism was and remains the canon of the American mentality. "The United States is a country of emigrants, each of whom (except Natives and African Americans) has decided to seek happiness in the New World, severing ties with his surroundings, to be himself, to feel like an independent person. Individualism becomes a prerequisite for becoming an American "[16]. On May 10, 1915, Woodrow Wilson delivered a speech in which he emphasized that it is impossible to become a true American if you continue to think of yourself as a group, because America is not made up of groups. A person who imagines himself to be part of a particular national group has not yet become an American. [17]. S. Berkovich asserted that from an ideological point of view, individualism, self-confidence, liberal democracy are the same true laws of nature and reason as the eternal truths of providence, hierarchy and divine law of kings, which America sought not to describe but to reject. For the Native American mind, such an attitude toward the community and the space that belonged to that community can be compared to the Christian apocalypse.

The significant gap between the axiological scale of European settlers and the Natives of North America in relation to the world around them and the place of human in it was not just unacceptable, it was staggering. Indigenous worldviews are built on the interconnectedness of everything in the world. Bonita Lawrence wrote that for an indigenous person, individual identity has always been conditioned by collective identity, even in the face of the external society of the colonizers. The laws that for years defined and controlled Indians distorted the ancient ways of identification not only with the collective consciousness but also with the earth itself [16]. Arthur Versluis explains that the importance of tribal culture was based not only on the understanding that people and nature are one, but also on the fact that humanity and the nature around them had a single spiritual basis and meaning. Whereas in the modern world people, trees, stones, animals, earth, sky, stars and waters are separate, isolated elements of the system, for indigenous people nature and man could not be divided as is customary now. There was a mystical connection between man and the surrounding landscape, between people and other living beings that coexisted with them [14]. Writer Kimberly Blaeser (Ojibwa) wrote that the earth itself is a long story. Many places have a connection with our stories, which only strengthens our connection with them. The heroes of L. Owens's novel The Dark River also speak about this.

T. King is convinced that despite the fact that the connection of indigenous peoples with the land is undoubtedly spiritual in nature, it is important not to reject the practical aspect that balances respect for survival. The ethical side of this phenomenon lies in the decisions of the community, preserved in folk songs and stories in which Native Americans spoke about the nature of the universe and its place in it, about the web of responsibilities that binds everything together. As the writer, a representative of the Mohawk nation, Bert Brant, writes: "We do not worship nature. We are a part of it". 


\section{Discussion}

Among Indian nations which managed to stay in endemic habitats are the Pueblo peoples, they were able to defend their lands despite repeated attempts to seizethem by Spain, Mexico, and the United States government. Not the least role was played by the skillful actions of pueblo lawyers. Leslie Marmon Silko, who has a law degree herself, created in the novel The Almanac of the Dead an autobiographical image of Wilson Wiesel Tale, a lawyer-poet, "healer and forerunner of the Lakota people." He utters a poetic speechaccusation, written in the style of poetic folklore of indigenous peoples, listing all violations of the rights and names of high-profile trials. A similar image of the Indian attorney was created by James Welch in the novel Indian Lawyer, where the hero abandons the political career of a Congressman from the state of Montana in favor to the protection of indigenous lands.

Special role for the defense of the rights and freedoms of Indigenous Siberians belongs to Eremej Ajpin, a person who closes to protect his way of life, language, faith, he is a pulsating point of intersection of culture and civilization, promoter of different worldviews and languages. The life of Ajpin as an "ethnic" writer, politician, and cultural figure fell on an era of severe cultural breakdown, and not just one. In such circumstances, not every person is able to remain a person, not to mention - simply stay alive, remain a fighter and a true writer, storyteller and chronicler of the souls of his people, a hunter from Varyogan - a point of view on the world could reveal the truth of ownership and commensurability with any other.

The books of Eremej Ajpin, I Listen to the Earth, Khanty, or the Star of the Morning Dawn stirred up the consciousness of the reading elite of Russia and the whole world. Ajpin introduced into Russian-speaking literature new themes, heroes, problems, a special lyrical tone of the narrative. The theme of nature occupies a special place in world literature, but he is a writer from the hunter family, one who has managed to do this in a new way, adding new colors to the mythological involvement in space and time. His story about the mother bear suicide after she lost her bear cub (Bear's grief) erases the boundaries between human and animal consciousness, connecting the world of people to something bigger. Shocked by the story of his grandfather, Ajpin was able to "see" this event and convey animal pain with human strength, a man became not only a witness, but also a participant in the tragedy, which testifies to the interconnection of the two worlds at the biosphere level. He could transmit the same pain to us about the fate of his people.

The writer's journey began with childhood memories that were included in the book "I Listen to the Earth". It contains many deep etudes-miniatures related to the discovery of the surrounding world by the storyteller, the theme of Mother is piercingly. The images of mother and Earth merge into mythological sacredness, giving rise to the great idea of honoring her as a life-giver and responsibility for her. And the writer tried to convey to his readers the "pain of the earth", and its miracles.

The Ajpin as a writer has the bitter right to become a chronicler of revolts against power, violence against the taiga and the persecution of shamans, impoverishment of reindeer herders. We are talking about a conflict between mainstream and traditional cultures and the impact of civilization on the biosphere of the living environment. But tales of oppression do not supplant from Ajpin's work the pictures of rapture by being, feelings of pride in his culture and feelings of happiness from joining it. He is trying to build a dialogue between culture and civilization.

A.Vashchenko recalled: "I will not forget that it was thanks to Ajpin that he stepped on the sacred land of Torum-Maa; I was happy to bring Ajpin 's acquaintance with the Indian writer Scott Momadey (another founder of great Indigenous literature) in the name of their possible cooperation. It seemed to me that an Indian writer, like a Khanty writer, today, not 
knowing about each other, will be poorer in their quests and victories - for each of them has close relatives far from each other ... And kinship must be strengthened! Therefore, together with Momadey I was lucky to visit the 50th anniversary of the writer. These and many other meetings seem to me significant, unique events".

Jill Momaday, one of Scott Momaday's daughters, is an actress and filmmaker. In 2017 she directed the documentary Return to Rainy Mountain which chronicles her relationship with her father and the braided histories of places where their Kiowa ancestors have traveled since the origins of the tribe. Return to Rainy Mountain is an imaginative action that takes viewers on a journey from the headwaters of the Yellowstone River to the present homeland of the tribe in southwest Oklahoma. In an interview Jill Momaday has said that she once heard the voice of her grandmother telling her to make such film, that she was "the magic link". This project had been on her mind for a long time came into being in that moment. There are magical moments captured in the film such as the breathtaking panoramic sweep of landscape in the high mountains and on the plains. As both Scott and Jill remark in the film, from here "you can see forever." It seems as if the viewer, too, is gazing into eternity. In an essay in the collection The Man Made of Words, Scott Momaday has written: "In dreams I read my mythic maps".This emphasis upon dreaming as a means of revealing deep knowledge of place and ancestry is apparent in Return to Rainy Mountain. Early in the film, Scott Momaday reveals that: "I dream of crossing the Bering Strait. I can see things there. We have a genetic memory, and at times mine reaches back to the Ice Age ..." This preoccupation with ancient ancestry is characteristic of Momaday's imaginative stretch, back to the origins of the Kiowa migration from northeast Arctic Asia down the coast of the North American continent. Elsewhere Momaday has written poems about this journey that he recalls vividly, as if it occurred yesterday. "The Blind Astrologers" from In the Bear's House is one of these striking poems [17].

There was another point of interconnection for two cultures happened in 2016, when the book "Meditation after the Bear holiday: poetical dialogues of N. Scott Momadey and Yury Velly" was published as a commemoration for Alexander Vashchenko. The cover for the book decorated with an abstract watercolor painting of Momadey himself, having portrayed a thoughtful brown witch-bear, who was blown up by a living sun rays. This is a little collection to have a set of eight poems, writing in the form of dialogue between the poets. Maister's shift and redirection Oleksandra Vashchenka and Claude Clayton Smith have given the readers a brilliant opportunity to see the signs of the Upper Traditions of Momadey (Kaiow tradition) and Valley (Nenets tradition). Translated and edited by Alexander Vaschenko and Claude Clayton Smith, the poems are seated in the oral traditions of Momaday (Kiowa) and Vaella (Nenets). Momaday provided seven visual images of Bear. The central essay "Always There, Always Here" was written by Alexander Vaschenko. Other contributors to the book (Susan Scarberry-García, Foreword; Andrew Wiget, essays, and Nathan Romero, poems) have enlarged the text with commentary, and Wiget and Scarberry-García's field photographs of northwest Siberia provide the reader with a strong sense of place. The poets became acquainted in northwestern Siberia, Russia, on several excursions between 1998 and 2004, and met for the last time in Santa Fe, New Mexico, USA in 2010. Upon first meeting at a fish camp on the Ob River, they walked through the wet grasses together, exchanging observations about the nature of indigenous life. When the poets embarked fish camp on a small fishing boat, they seriously discussed the nature of bears. Vaella, a bear hunter, told Momaday about the sacred pact between hunter and bears which are sacrificed for ceremonial reasons. The storied imagery in Vaella's poems in Meditations springs from having witnessed his wife's Khanty community participating in bear feastival rituals, and his experience of caring for the domestic reindeer in his own Nenets family camp. 
Native American author was so impressed hearing the particulars of Vaella's life that he began the poetic sequence with "Summons," crying out for a bear doctor, for a healer. "Where is the bear doctor? Where is he? / Who will outfit me for my journey?" Vaella responded to him in the poetic form: "And here I come! / I await you on your path./ In my entire life I have no closer brother. / In my entire life no better companion./ We can compare our strides. / We can exchange our growls. / We can cross our stares. / May our path never narrow. / And here I come!" In this initiating poem, Vaella became the bear doctor, declaring his love for Momaday as a souyl brother. Embodied as bears, the poets share a path, a journey through the taiga. Momaday expressed this relationship: "There is only one story, but there are many stories in the one." Meditations in the book After the Bear Feast is a story of reflection on the indigeneity and immortality, filtered through the lens of loss. Yet there is still hope for the intergenerational transmission of cultural knowledge through oral tradition, art and writing. Meditations After the Bear Feast is a notable transcontinental poetic conversation only possible in the last two decades, since indigenous encounters such as this were previously prohibited by the politics of nationstates [17].

Most of the Indigenous people believe that their nations were created at the territory they live now, so this locus is the center of the universe for them. The past and the future are understood by the natives at the level of physically perceptible, sound, visual, tactile and sensory sensations, thus the concept of the sacred landscape is formed, and each nation has its own notion of it. Vladimir Sangi wrote about the worldview of autochthonous peoples of Siberia: "The people who lived there were related to trees, animals and birds, marine plants and fish. Either the soul of people and nature is one, or the truth is that human clans were conceived either by bear or by an eagle, and others emerged in the marriage of brave hunters and tender larch, and if one of the people died in the ocean, he resurrected as a fish or as underwater plants". The spatial identity of the indigenous people is supported by their spiritual beliefs, thanks to which there is a close symbiosis between the earth and people. Archaeologists date the traces of human settlements, which they found almost throughout North America and Siberia, to about the twelfth century BC, this is much earlier than the heyday of the civilizations of Egypt, China, Israel or any other civilization known in the Old World. In the eyes of indigenous communities the antiquity of existence on a particular land is an important fact of self-identification of indigenous nations. That is why the famous writer and literary critic Louis Owens (Chocto-Cherokee) emphasized that "Indians are an important part of the complex relationships in the world that we now call the environment".

\section{Conclusions}

The vast majority of indigenous writers emphasize the importance of the connection between the ecology and the present life, reflected in the concept of historical memory and space, it is this longevity that gives meaning and significance to modern indigenous identity. This gives rise to the notion of historical memory, which S. Hall calls the mysterious ability to experience national history as one's own drama. To deprive a person of ecological memory means to deprive him of his culture (in the sense of the quality of being), to deprive him of his spiritual self-recognition, and thus to kill his personality.

In the process of adaptation of certain indigenous ethnic groups to the natural and social conditions of life in communities, the corresponding realities of culture and mental traits emerged, from which ethnic self-consciousness appeared, which in turn produced the spatial identity of a particular indigenous nation. The values of culture helped a person to direct his/her life and activities in the direction approved by society, thanks to which there was a self-realization of each individual as a human and a member of ethnocultural society. 
The identity of indigenous nations depended primarily on the crystallization and manifestation of the integrative factors implicitly present in the minds of the people.

Space and time are meaning-making ecological factors in the works of indigenous writers, which form the figurative, compositional and meaningful vectors of their works, they connect together important events of history, are a kind of cure for today's problems and complexities of mainstream society. Ecological memory as a symbolic image and as a living being unites disparate semantic and conceptual spaces, defining hidden textual meanings, actualizes the complex problems of the existence of indigenous peoples in modern times.

Indigenous writers sometimes shift temporal-spatial layers, superimposing chronotopic planes, suspending astronomical time, thus destroying the boundaries of the real world and at the same time creating fascinating spaces that are an important part of the indigenous ecologiacal identity. Thus, spatiality functions in fictional texts as a stylistic device designed to express the opposition of different worlds.

\section{References}

1. S.V. Hunsaker, Autobiography and National Identity in the Americas (Charlottesville\&London: University Press of Virginia, 1999)

2. V. Jr. Deloria, God is Red (New York: Grosset \& Dunlap (1973)

3. A. M. Jr. Josephy, 500 Nations. An Illustrated History of North American Indians (New York : Gramercy Books, 1994)

4. J. Nagel, False Faces: Ethnic Identity, Authenticity, and Fraud in Native American Discourse and Politics (New Brunswick, NJ: Transaction Publishers, 2000)

5. L. Owens, Mixedblood Messages: Literature, Film, Family, Place 9Norman: University of Oklahoma Press, 1998)

6. J.D. Miner, Beasts of Burden: How Literary Animals Remap the Aesthetics of Removal, Decolonization: Identity, Education and Society 3, 2, 60-82 (2014)

7. K. Lincoln, Native America Renaissance 9Berkeley: U of California Press, 1983)

8. A. Macdonald, G. Macdonald, M.A. Sheridan, Shape-shifting Images of Native Americans in Recent Popular Fiction. - Westport-London: Greenwood Press (2000)

9. P.G. Allen, The Sacred Hoop: Recovering the Feminine in American Indian Traditions (Boston: Beacon Press, 1986)

10. J. Tripathy, Toward as Essential Native American Identity: a Theoretical Overview, The Canadian Journal of Native Studies 26, 2, 313-329 (2006)

11. G. Vizenor, J. Doerfler, The White Earth Nation. Ratification of a Native Democratic Constitution (Lincoln-London: University of Nebraska Press, 2012)

12. S. Bercovich, American Canon and Context. History in a Time of Dissensus, American Literature 58, 1, 99-107 (1986)

13. B. Lawrence, Gender, Race, and the Regulation of Native Identity in Canada and the United States: An Overview, Hipatia 18, 2, 3-31 (2003)

14. A. Versluis, The Sacred Earth. The Spiritual Landscape of Native America (Rochester, Vermont: Inner Traditions International, 1992)

15. K. Blaeser, Gathering of Stories. Stories Migrating Home. In: A Collection of Anishinaabe Prose (Bemidji: Loonfeather Press, 1999) 
16. T. King, The Truth about Stories. A Native Narrative (Minneapolis: University of Minnesota Press, 2008)

17. S. Hall, Cultural Identity and Diaspora In: J.Rutherford (ed.), Identity: Community, Culture, Difference (London: Lawrence and Wishart, 1990) 